\title{
A social role for churches and cultural demarcation: How German MEPs represent religion in the European Parliament
}

\author{
ANNE JENICHEN (jenichen@uni-bremen.de) \& HENRIKE MÜLLER (henmue@uni- \\ bremen.de) \\ Centre for European Studies (CEuS), University of Bremen
}

\begin{abstract}
The article deals with the question of how German members of the European Parliament (MEPs) represent the German model of religion-state relations at the European level. Based on a survey and interviews with German MEPs as well as a content-analysis of German MEPs' speeches, motions and parliamentary questions during the $7^{\text {th }}$ term of the European Parliament, the article demonstrates that this model is represented in three dimensions: First, German MEPs reflect the close cooperation between the churches and the state in Germany, primarily on social issues, through largely church- and religion-friendly attitudes and relatively frequent contacts with religious interest-groups. Second, by referring to religious freedoms and minorities primarily outside the EU and by placing Islam in considerably more critical contexts than Christianity, German MEPs create a cultural demarcation line between Islam and Christianity through their parliamentary activities which is similar, though less politicised, to cultural boundaries often produced in public debates in Germany. Third, the article illustrates similar patterns of religious affiliation and subjective religiosity among German parliamentarians in both the European Parliament and the national parliament, which to some degree also reflect societal trends in Germany. Yet our data also suggests that European political elites are more religious than the average German population. If the presence of religion in terms of religious interest- groups and arguments is included, the German parliament appears to be more religious than the European Parliament.
\end{abstract}

\section{Introduction}

Germany is the largest member-state of the European Union (EU). Germans thus constitute the largest national group within the European Parliament (EP). Germany can furthermore be considered a unique case in Europe in terms of how religion and the state as well as the political sphere are linked with each other. The close cooperation of the state with the Protestant and Catholic Churches, particularly on issues of providing social welfare, and the 
presence of two major Christian faiths, render Germany a case that is worth studying in the context of religion and politics in the EU.

Drawing on the assumption that national models of church-state relations (in a broader sense) affect the perceptions and behaviour of parliamentarians, we examine in this article whether and how the German members of the EP (MEPs) represent the German model of publicly dealing with religion at the European level. This German model is, on the one hand, characterised by a close cooperation between church and state, primarily in the sphere of social welfare provisioning, and thus by a privileged and acknowledged role of religion in the public sphere. On the other hand, there is a continuous trend of individual and societal secularisation observable, and religion increasingly becomes politicised as a factor contributing to social conflict. It is primarily Islam which is used to mark cultural boundaries between 'us' (the - Christian or non-religious - majority society) and 'them' (allegedly primarily Muslim immigrants).

Are these trends reflected by the perceptions, attitudes and activities of German MEPs? Drawing on data obtained via the RelEP survey, semi-structured interviews with German MEPs (conducted between 2011 and 2012 in Brussels, Berlin, Hamburg and Bremen) and a qualitative content-analysis of German MEPs' speeches, motions and parliamentary questions during the $7^{\text {th }}$ parliamentary term (2009-June 2013), we shall illustrate throughout the following sections how the German model is indeed mirrored in several respects. The German MEPs consider the churches and religious interest groups to be legitimate partners in supporting social interests rather than religious interests. The analysis of parliamentary activities reveals a primarily religion-friendly attitude on the part of the German MEPs, which is facilitated by addressing religion primarily as an issue of human rights, especially freedom of religion and the rights of religious minorities, allowing a relative consensus between believers and non-believers and different denominations on issues of religion. However, the overwhelming majority of these activities refer to religious freedoms and minorities outside the EU, and place Islam in considerably more critical contexts than Christianity, disclosing a similar cultural demarcation line between 'us' (Christian Europeans) and 'them' (extremist Muslim outsiders) to that which is observable in public debates in Germany. Differences between political groups in this regard are important to consider though, with the Group of the European People's Party (EPP) much more affirmative of Christianity and critical of Islam than, for instance, the Greens and the Left.

The article is divided into three parts. In the first part, we describe the state-church regime, its historical development, and the role of the churches in Germany, as well as the 
state of secularisation and religious pluralisation and the public politicisation of religion in order to delineate the German model of church-state relations. In the following part, we present our findings on German MEPs in order, first, to find out about how relevant they perceive religion to be in the workings of the EP, and, primarily, to demonstrate how their activities and attitudes reflect the predefined German model. Subsequently, we ask whether their religious affiliation and religiosity mirror societal trends in Germany. In this part, we also turn to the national level in Germany and investigate religious affiliation and the religiosity of members of the German Parliament (Bundestag) to approach this question.

\section{Religion and politics in Germany}

The current church-state regime in Germany is based on a compromise laid down in the constitution of the Weimar Republic in 1919. The compromise consisted in rejecting a state church regime (favoured by conservative and church-friendly parties), but allowing the churches a privileged status under public law, instead of strictly separating them from the state according to the French or US pattern (favoured by the parties of the left). The constitution furthermore introduced freedom of conscience and religion and the autonomy of religious communities (Cavuldak 2013, 308-314).

After the Second World War, the Federal Republic of Germany (FRG) took over the religio-political compromise of the Weimar Republic. The new constitution additionally introduced new provisions, in the end leading to a stronger integration of church and religion into the democratic state than before, including an explicit reference to God in the preamble ${ }^{1}$, and the introduction of religious education in state schools. State constitutions were likewise extended. The closer integration resulted from the experiences with the Nazi regime. Facing a politico-moral vacuum and economic deprivation after the war, many Germans in the western part of the country sought hope and refuge in the churches (Cavuldak 2013, 315-316). The FRG furthermore used the close cooperation with the churches to distance itself from the GDR and its publicly prescribed atheism. The government of the GDR actively repressed the churches for ideological as well as power political reasons, resulting in a situation for the churches characterised by scarce resources, lack of societal recognition and continually decreasing membership (Pickel 2013, 78-79; Thériault 2004, chap. 2). Despite this dichotomy

\footnotetext{
1 'Aware of its responsibility to God and the people, inspirited by the willingness to serve peace in the world as an equal member of a united Europe, the German nation, by virtue of its constitutional power, has given itself this constitution' (our translation).
} 
of state-church relations, reunification did not seriously raise the question of the religiopolitical regime again. With the exception of some politicians from the Greens (formed in the 1993 merger of the West German Green Party and the East German Alliance'90) and the Party of Democratic Socialism (PDS), the successor party of the Socialist Unity Party of Germany (SED), a large political majority did not see the necessity to rearrange the regime and therefore opted for nationally adopting the western one (Cavuldak 2013, 318).

The current church-state system is characterised by separation but a considerable degree of cooperation. It can therefore be defined as a 'regime of partial establishment' (Minkenberg 2013, 58) or, citing the German canon lawyer Ulrich Strutz (1925), 'limping separation between state and church' (Cavuldak 2013, 314). Officially recognised religious communities can operate as 'corporate bodies under public law', allowing them to raise taxes from their registered members (German constitution, art. 137.6), usually collected via the state as part of official income taxes. Further privileges connected with this status concern taxation privileges, permission to provide religious education in state schools and establish theological faculties in state universities, the right to provide pastoral care in prisons and military academies, and a voice in public bodies, such as public service broadcasting authorities or ethics committees (Cavuldak 2013, 314, 325). The two major churches, the Roman Catholic Church and the Protestant Church, ${ }^{2}$ automatically received this status after the constitutional clause was introduced in 1919, whereas other religious communities could receive it upon application. ${ }^{3}$ Islamic communities, though, have been unsuccessful in achieving this status so far, failing, among other reasons, because of the missing church-like institutional structure and representative bodies (Cavuldak 2013, 324). However, there are efforts by the state to improve dialogue with Islam, for example through convening 'German Islam Conferences' (2006, 2007, 2011 and 2013) (Cavuldak 2013, 324-327; Tezcan 2011; official website http://www.deutsche-islam-konferenz.de/DIK/DE/Startseite/startseitenode.html). Further regulations of religion fall into the competencies of the 16 states (Länder). Cooperation is furthermore regulated by concordats and contracts between the German federal state as well as some of its states with the Holy See and with officially recognised religious communities, primarily the two major churches.

\footnotetext{
2 The Protestant Church consists of different units, called Landeskirchen, which together form the Evangelical Church of Germany (EKD).

3 The condition for receiving this status is the guarantee of continuity proven by a statute and a certain number of community members. Religious communities not operating under public law receive a civil law status as a private registered association (German constitution, art. 137.5).
} 
An important part of the privileged role of the churches in Germany is their official inclusion into the social welfare system. The outcomes of conflicts between church and state, as well as between denominations, on the expanding role of the state in welfare provision in the late nineteenth and early twentieth centuries had a considerable impact on the formation of different types of welfare states in Europe (Manow and van Kersbergen 2009). In Germany, the peaceful resolution of this conflict yielded a compromise between religious and secular forces as well as Catholic and Protestant camps. Religion, consequently, became an institutionalised partner of social welfare provisioning.

The two welfare organisations of the churches, the Catholic 'Caritas' (founded in 1897) and the Protestant 'Diakonie' (founded in 1833), are the largest umbrella organisations of the German social welfare system. They are the largest actors and employers in health services and social work, including health care, elderly care, youth welfare, centres for migrants, the homeless, the disabled, and rescue services. About $50 \%$ of social care is delivered through these organisations, publicly financed through a variety of insurance schemes but administered by the churches (Davie 2012, 594-595; Göçmen 2013, 11-13; Willems 2007, 317-318). Besides national welfare, the churches also run large development agencies which are important actors in German development aid. Even though the two Christian welfare associations have lost some of their privileges since the 1990s as a result of the pluralisation of the German welfare system - changes in its public financing which responded to the increasing (religious) diversity of German society - the institutionalised position of the churches in social welfare provisioning is still relatively stable (Göcmen 2013, 12-13). Facing societal secularisation processes, the German churches derive much of their legitimacy from this social role.

Levels of church membership, church attendance and individual religiosity have been decreasing in Germany since the 1970s. Both parts of Germany have been affected by individual and societal secularisation processes, though starting from very different levels. In eastern Germany, church membership decreased from 90\% (1953) to 27\% (1989) to about $26 \%$ (2008), one of the lowest levels of church membership in the whole of Europe. In western Germany, by contrast, despite slightly decreasing numbers over time, still almost $80 \%$ of the population is affiliated with one of the two major churches (Pickel 2013: 79-81). Yet active membership is in decline in the western part of Germany as well: Only about $25 \%$ of the western German population regularly attends church services (Pickel 2013, 82). Only about $10 \%$ go to church at least once a week; in eastern Germany this number is even lower: 3\% (Elff and Rossteutscher 2011, 113-114). The share of Catholics in this group is larger than 
that of Protestants as the Catholic faith puts a stronger emphasis on 'practical' worship (Pickel 2013, 82; Elff and Rossteutscher 2011, 115). In both parts of the country the numbers are shrinking. The situation regarding subjective religiosity looks similar: about $25 \%$ of the western German population and more than $50 \%$ in eastern Germany do not believe in God. In East Germany, about 25\% define themselves as atheistic (Pickel 2013, 83).

Secularisation in Germany, both eastern and western, is subject to a generational effect. Younger age cohorts less frequently attend church services, are less frequently church members and tend to be less religious than older age cohorts (Pickel 2013, 84). Secularisation processes are furthermore observable not only at the individual level but also at the societal level. Functional differentiation is highly acknowledged in the German population, in the west as much as in the east, and irrespective of confessional affiliation. Only a few citizens want a stronger influence of religious authorities, for instance, on elections or political decisionmaking (Pickel 2013, 86).

At the political level, however, religious-secular and denominational divisions still shape electoral behaviour in Germany: in both western and eastern Germany there is a clear correlation between support for the Christian Democratic Party (CDU) or the Christian Social Union (CSU) and regular church attendance. Catholics tend to vote for the CDU/CSU much more frequently than Protestants (Elff and Rossteutscher 2011; Liedhegener 2011). Secular people, at the other end, primarily support the Greens (in the west) and the Left (in the east) (Pappi and Shikano 2002; Liedhegener 2012).

The programmes and attitudes of the major political parties in Germany have however converged on the matter of religion. The Christian democratic parties have increasingly stressed their autonomy from confessional divisions and church dogmas, and have started to address non-Christian voters as well (Bösch 2013, 211, 213; Gerngroß 2010, 88ff; Liedhegener 2012, 243). Compared to other Christian Democratic parties in Western Europe, references to Christian social doctrines and religion are relatively few. It therefore has been contested how Christian both parties still are (Gerngroß 2010, 93; Liedhegener 2012). Meanwhile the Social Democrats (SPD), the Liberals (FDP) and the Greens, all three initially more critical towards religion, have become more religion-friendly, in terms of their members, office-holders, programmes and voters alike (Hering 2011; Liedhegener 2012, 252). The only exception from the convergence of the parties is the Left party (Die Linke), which still constitutes the secular pole in the German party system (Liedhegener 2012, 252; Pappi and Brandenburg 2010). 
Germany shows an increasing trend towards religious pluralisation (Table 1). Even though the proportion of Muslims is still relatively low, resentment against Islam and Muslims in Germany is gaining currency (de Nève 2013; Götze, Jaeckel, and Pickel 2013). Increasing levels of religious plurality furthermore challenge the prevailing church-state system in Germany with its privileging of Christian and Jewish communities. Some have therefore argued that either the 'limping separation' should be extended and applied to all religions or religion separated more strictly (Cavuldak 2013, 332; Pickel 2013, 98).

Table 1. Religious communities in Germany 1990-2010 (\%).

\begin{tabular}{|c|c|c|c|}
\hline & 1990 & 2003 & 2010 \\
\hline Protestant & 36.9 & 31.3 & 29.4 \\
\hline Catholic & 35.4 & 31.3 & 29.4 \\
\hline Muslim & 3.7 & 3.9 & 4.6 \\
\hline Other & 1.6 & 1.7 & 1.8 \\
\hline No confession & 22.4 & 31.8 & 32.5 \\
\hline
\end{tabular}

Source: Götze, Jaeckel, and Pickel 2013, 284.

Growing levels of religious pluralisation and Islamophobia have contributed to an increase in public discourses on religion (Pickel 2013, 67). Since religion is often problematised as a cause of conflict in these discourses, this politicisation does not contradict the constant loss of importance of religion at individual and societal levels; rather, both processes are mutually constitutive (Pickel 2013, 96). Most prevalent have been debates on Muslims and Islam in Germany, such as on Muslim headscarves in public institutions, on the willingness of young Muslims to integrate, or on violent Salafism. These debates often confound issues of religion and migration (Spielhaus 2013) and position a 'discrete cultural Christianity' against an 'ostentatious' Islam (Wohlrab-Sahr 2003). However, the role of religion in society has also been debated with regard to Christianity and the Christian churches, focusing, for example, on crucifixes in public institutions, on religious education in state schools, on Pope Benedict XVI speaking in the German Bundestag, on sexual and physical abuse of children by members of the clergy and other church employees, on working contracts within church and church-related welfare institutions, and on the refusal of emergency contraception in confessional hospitals.

The churches have actively participated in most of these debates, as well as in debates on moral and ethical issues such as stem cell research, prenatal diagnosis and late-term abortions, euthanasia, equal rights for same-sex relationships and family policy. They do not 
restrict their participation in public discourses to an exclusively sacral sphere, where the preservation and practice of religious rituals takes place, but have transformed themselves into a particular sort of modern interest group. ${ }^{4}$ They not only publicly defend their institutional interests in keeping their privileged legal status in Germany and promote their value orientations, for example on marriage, family, sexual orientation, education or medical ethics, they also, according to their abovementioned social role, put forward moral demands, speaking up on issues such as social justice, asylum law, climate change, the environment, peace, development and human rights (Gerngroß 2010, 92; Sebaldt and Straßner 2004, 122127; Willems 2007, 321-322). European integration has been supported by both the Catholic and the Protestant Churches in Germany (Minkenberg 2009, 1203-1206).

In sum, the model of dealing with religion in Germany, facing continuing trends of individual and societal secularisation as well as religious pluralisation and the politicisation of religion, is located between close cooperation with the churches, primarily on issues of social justice and development, on the one hand, and using religion, primarily Islam, for cultural demarcation, on the other. We now turn to the EP to explore whether and how German MEPs represent this model through their perceptions and parliamentary activities.

\section{German members of the European Parliament and religion}

\section{Studying the German group in the EP}

The 99 Germans represent the largest group of MEPs in the EP. In the seventh parliamentary term (2009-2014), the largest share of the German MEPs belongs to the European People's Party (EPP), the second-largest group to the Progressive Alliance of Socialists and Democrats (S\&D). Other MEPs identify as Greens (Greens/EFA), Liberals (ALDE) and members of the Left (UEL/NGL) (Table 2).

We approached the German group in the EP using three different methods. First, 25 German MEPs filled in the RelEP questionnaire (response rate: 25.25\%). The distribution among political parties is fairly representative, with a slight bias towards the Greens, and a disproportionately low share of Liberals, female MEPs, and MEPs born in the 1960s (Table 2). There might be a bias towards MEPs with stronger interests in religion (or in keeping

4 The classification of the churches as organised interests, however, is contested (Willems 2007, 318321). 
Table 2. Sample of the German case study.

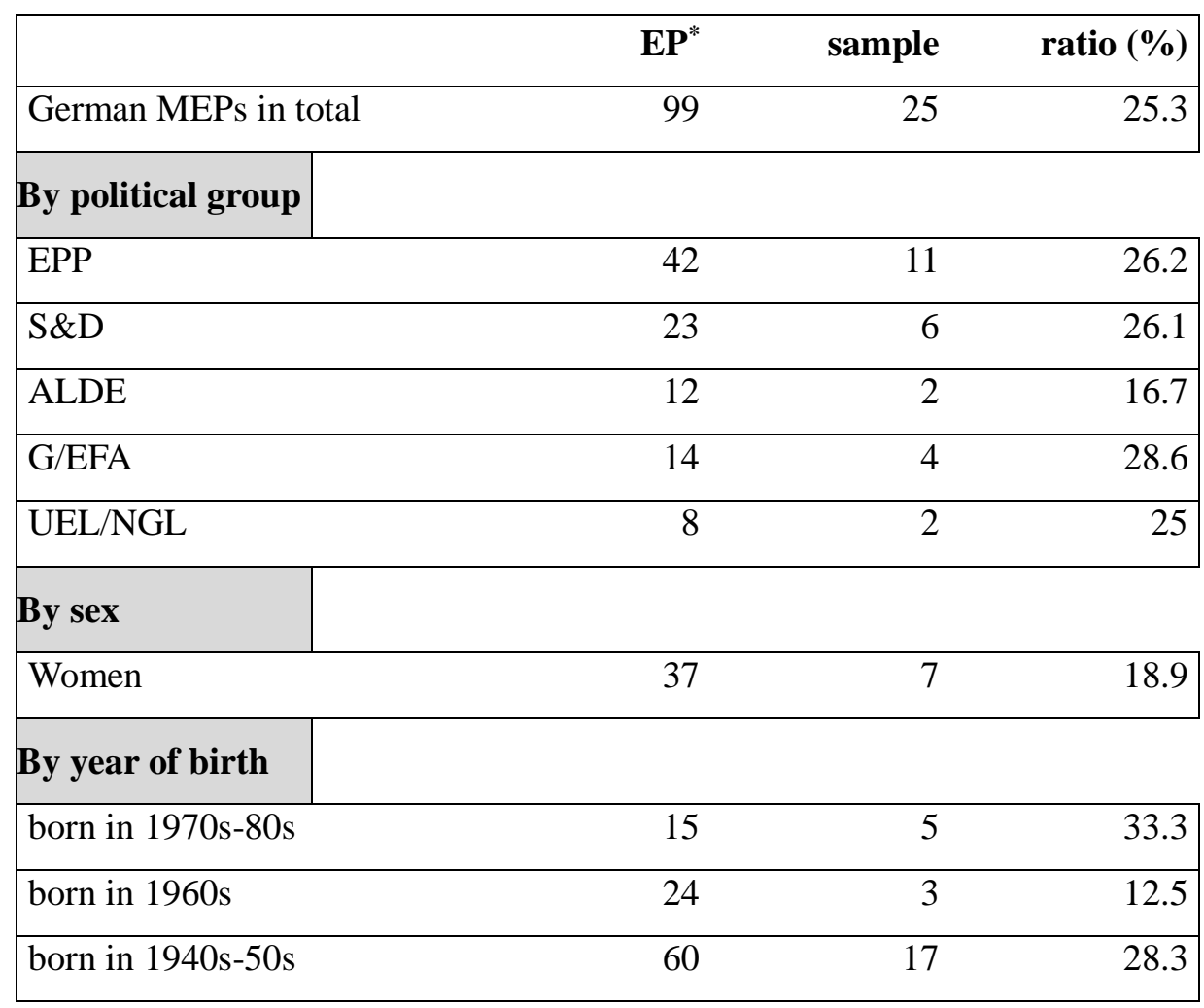

* Situation at time of survey and interviews (October and November 2011).

religion out of the European political sphere) within the sample as many rejections of interview requests were based on the statement that the MEP asked would not be an expert on or interested in the issue and could therefore not provide any information on the subject. We therefore complement the data from the survey with qualitative interviews with 20 MEPs out of the 25, who filled in the questionnaire and who were willing to be interviewed as well, and, finally, a qualitative content-analysis of all German MEPs' parliamentary activities.

The qualitative content-analysis covers all speeches in plenary, motions for resolutions, and parliamentary questions of German MEPs during the $7^{\text {th }}$ parliamentary term (cut-off date: 7 June 2013). The data were collected from the personal homepages of the MEPs on the website of the EP. First, we researched all activities (5324 speeches, 2334 participations in motions, 2848 participations in questions ${ }^{5}$ ) using various keywords relating to religion. ${ }^{6}$ In a second step, we sorted out all contributions which only casually mentioned one of the keywords without really focusing on the issue of religion. We then coded the

5 As the research presented here uses the MEP as level of analysis and since most motions and questions are issued by a group of MEPs, these numbers do not represent the number of motions and questions but exceed it.

6 We thank Johanna Voß for her assistance in this research. 
remaining material (91 speeches, 190 motions, 37 questions) using five categories: (1) status of religion in the document (primary or secondary); (2) denominations referred to; (3) territoriality (EU internal affairs: certain member states; or EU external affairs: accession candidates, neighbouring countries, third states); (4) framing of religion (positive: for example as something to protect; or negative: for example a factor contributing to conflict); (5) context (for example human rights, terrorism).

\section{The impact of religion on the way the EP works}

One of the first questions when reasoning about religion in the EP is about the relevance and specific impact of religion. According to the majority of our interview partners, religion has an effect on the overall functioning of the EP, though a relatively small one. In order to assess the overall effect of religion in the EP, we should differentiate between different understandings of the religious effect.

At the level of personal attitudes, beliefs and values, religion, at least for religious MEPs, is a ubiquitous force, constantly affecting parliamentary work, although this might not be expressed explicitly. Some MEPs furthermore stressed the Christian cultural tradition which arguably affects decision-making, even of non-religious MEPs.

Religious issues and arguments, by contrast, do not come up that often; only when corresponding themes are on the agenda. This uncommonness of explicitly religious issues in the EP is confirmed by our content-analysis: only $1.7 \%$ of speeches by German MEPs in the plenary, $1.6 \%$ of participations in parliamentary questions and $20 \%$ of participations in motions for resolutions included an explicit reference to religion, and in all these only $21.1 \%$ focused primarily on religion, the remainder only briefly mentioning religion, primarily freedom of religion.

The effect of religion in terms of direct influence of religious actors is perceived by the German MEPs to be rather marginal.

There are three dimensions which might affect how religion impacts the work of the EP: nationality, group membership, and denominational differences.

First, national differences, according to the surveyed German MEPs, have the largest impact on the importance of religion. Slightly more than half of them (13) thought that MEPs from some countries, such as Poland, Italy, Spain and Portugal, were more inclined to use religious arguments, whereas MEPs from France and Nordic countries were reluctant to do so. The German group was often located somewhere in the middle because of its strong diversity 
in terms of religiosity and religious affiliation. However, other German MEPs did not see much influence of nationality, because of diversity in other national groups as well. Some of the interviewed MEPs ascribed the impact of the national dimension less to the extent of religiosity in member-states than to their traditions of church-state relations. These traditions affect how MEPs from different countries deal with the issue of religion, even if they are not part of the national majority. The historical and cultural traditions thus might have a larger impact than individual religiosity and confessional belonging.

Second, political group membership is assessed to be less effective. Most surveyed German MEPs think that religion has no effect on group differences or even blurs them, because the political groups in the EP are represented by both religious and non-religious MEPs. There is only one exception: most surveyed MEPs agreed on the fact that religion is most important for the Christian Democrats in the EPP. The EPP in general, even though represented not only by Christian Democrats but also by other conservatives, seems to be closest to religion. For instance, it organises a range of religious events and meetings through its Group on Intercultural Dialogue and Religious Affairs. ${ }^{7}$ As far as we know, there are no corresponding working groups within the other political groups in the EP.

Third, denominational differences are considered to be the least effective factor in the functioning of the EP. The majority of the consulted German MEPs (16) saw no impact at all. Some German MEPs, though, observed a stronger commitment of Catholic and Orthodox Christians to their church and its positions than members of other denominations. However, most MEPs also emphasised their lack of knowledge about the confessional adherence of most of the other MEPs and consequently could not perceive corresponding differences.

In the end it might be the intersection of these three dimensions, culminating in Catholicism: MEPs from primarily Catholic countries, from the EPP as dominated by Catholics, and of the Catholic faith were, in the view of some interviewed MEPs, most prone to religious influence on the politics of the EP. However, most MEPs also stressed the diversity both within national and political groups in the EP on issues of religion as well as others, making exceptions to the rule common and clear-cut distinctions impossible. In the end, when substantial policy issues are concerned, political divisions appear to be stronger than religious ones.

\section{Religion in the political practice and socialisation of German MEPS}

7 The phrase 'religious affairs' was dropped in 2012. However, the group still works primarily on issues of religion (http://www.eppgroup.eu/intercultural-dialogue). 
The privileged social role of the churches in Germany can also be recognised in how German MEPs interact with religious interest-groups. Although most of them consider contacts with religious interest-groups to be secondary in their work, the frequency of their contacts is comparatively high.

Half of the surveyed German MEPs frequently deal with religion in their parliamentary work. More than half of the MEPs (52\%) think that religion primarily plays out as a personal source of inspiration for decision-making, especially for the German MEPs who consider themselves religious. The consulted MEPs who do not define themselves religious do not perceive any impact of religion on their work (12\%) or see religion only as an external phenomenon that sometimes needs to be dealt with (20\%). Contact with religion as an interest-group, trying to influence the work of MEPs, is only secondary in the MEPs' perception, despite frequent contacts between some of the German MEPs and religious interest- groups.

Most of the included German MEPs have regular contacts with religious (or secularist) interest-groups. Contacts are somewhat more frequent than those of domestic German politicians, but considerably more frequent than the average for MEPs from other countries (see Foret in this volume) and for domestic parliamentarians from other countries (Table 3). The survey of German MEPs suggests a strong positive association between the religiosity of the MEP and the frequency of contacts (all MEPs who reported contacts at least once a month or once a week were religious). The political factor, in contrast, seems to be less relevant. Although the MEPs with contacts at least once a week are all members of the EEP, MEPs with contacts at least once a month or several times a year come from all parties, including the UEL/NGL. The most frequent contacts are with the

Table 3. Frequency of contact with religious and ethical interest groups (\%).

\begin{tabular}{|l|c|c|c|c|c|}
\hline & $\begin{array}{l}\text { At least once } \\
\text { a week }\end{array}$ & $\begin{array}{l}\text { At least once } \\
\text { a month }\end{array}$ & $\begin{array}{l}\text { Several times } \\
\text { per year }\end{array}$ & $\begin{array}{l}\text { Several times } \\
\text { in } \\
\text { legislative } \\
\text { period }\end{array}$ & $\begin{array}{c}\text { (Almost) } \\
\text { never }\end{array}$ \\
\hline $\begin{array}{l}\text { MEPs: How often do } \\
\text { religious and ethical } \\
\text { interest groups contact } \\
\text { you? }\end{array}$ & 12 & 24 & 44 & 4 & 16 \\
\hline MPs from Germany * & 6.4 & 33.9 & 54.6 & & 5.2 \\
\hline
\end{tabular}




\begin{tabular}{|l|c|c|c|c|c|}
\hline & & & $\begin{array}{c}\text { (at least once } \\
\text { a year) }\end{array}$ & (not included) & \\
\hline $\begin{array}{l}\text { Average of MPs from } \\
\mathbf{1 5} \text { countries (Western } \\
\text { and Eastern Europe, } \\
\text { Israel)* }\end{array}$ & 4.7 & 15.9 & 50.8 & (not included) & \\
\hline
\end{tabular}

* Unpublished data from the PartiRep Comparative MP Survey (Pascal Delwit, Jean-Benoit Pilet, Giulia Sandri, ULB, Brussels) (only churches and religious organisations)

German Catholic and Protestant Churches. Other contacts include: Caritas; the Commission of the [Catholic] Bishops' Conferences of the European Community (COMECE); Eurodiaconia; the Conference of European Churches (CEC); the World Youth Alliance; B'nai B'rith International; the European Jewish Congress; Laïcite; Brot für die Welt, Misereor (relief organisations of the German churches); the German Humanist Union. These contacts are of a wide variety: information, policy briefs and position papers sent by email or mail; invitations to panel discussions, conversations on certain topics, receptions, religious ceremonies; meetings with representatives of religious communities; personal contacts via telephone and lunch meetings. Religious organisations furthermore provide expertise and contacts to interesting interlocutors, and serve as forums for discussions. Most of the interviewed German MEPs have more contacts in their electoral districts in Germany than at the European level.

The German churches are regarded by many of the German MEPs as 'normal' interest groups and vital contributors to interest mediation. The contact is also often perceived as a dialogue rather than unilateral lobbying, particularly by religious MEPs. For most of the interviewed German MEPs, the commitment of the churches and non-governmental organisations with a religious background is particularly visible on substantial policy issues (such as poverty; environmental protection; genetic engineering; development cooperation; world hunger; agricultural policy; human rights; issues of social justice; the rights of refugees, migrants and minorities; fair trade; recently also the financial crisis), rather than on religious or institutional interests of the churches. This primarily altruistic, non-commercial role of the churches at the European level, resembling their social role in German politics, provides them, in the eyes of most of the consulted MEPs, with legitimacy, and explains their relatively frequent contacts. It furthermore distinguishes them from other more traditional churches from Eastern Europe and from small groups of fundamentalist Christians, which in the view of two German MEPs do not possess the German tradition of social responsibility and often agitate against European values. 
Given the widespread recognition among German MEPs of religious communities, primarily the churches, as legitimate partners in pursuing European values, it is not surprising that the majority of the German survey respondents across believers and non-believers as well as different religious affiliations and political groups accept the EP presidents' efforts to enter into dialogue with religious communities. Only one atheist S\&D member rejected even this as an illegitimate interference of religion into the political sphere. Two non-religious Greens furthermore demanded that secularist and philosophical groups and intellectuals should also be invited.

Yet the EP does not have a socialising effect on German MEPs regarding their views on religion. $92 \%$ of the surveyed German MEPs have not experienced any changes in these views during their service in the EP.

\section{Policy sectors and thematic debates in which religion is most salient}

German MEPs across all parties display a largely affirmative notion of religion, indirectly mirroring the cooperative, religion-friendly model in Germany. Religion is primarily framed in their parliamentary activities as something to protect, facilitated by placing it mainly in the context of protecting human rights. However, by referring to the issue as one to primarily focus on abroad, parliamentary activities also contribute to drawing a demarcation line between 'Christian Europe' and 'Muslim violators of human rights abroad'.

The content analysis reveals that the policy sector in which religion is most salient in the parliamentary activities of German MEPs is external relations. Almost $90 \%$ of all participations in speeches, motions and questions refer to EU external affairs, primarily in third countries $(68 \%)$ but also in countries included in the European Neighbourhood Policy (ENP) (28\%) and in accession candidates (4\%). Accordingly, most of the German MEPs who are most active on religion (in terms of the number of their religion-specific parliamentary activities), or who define themselves as religious, are members of the committee on Foreign Affairs, including its two subcommittees on Human Rights and Security and Defence. The majority of the surveyed German MEPs (72\%) thinks that religion is an issue playing a role in EU external relations. However, as one MEP rightly pointed out, the competences of the EP in the EU's external relations are limited. Its politics on religion with its strong emphasis on human rights, therefore, is primarily of symbolic significance.

Human rights is an area which is particularly suitable for reconciling different views on religion. The principle can easily be deduced from Christian values of altruism, equity and 
human dignity, but can also be based on a non-religious humanist perspective. However, in the views of some Christian MEPs, it is primarily the joint Christian tradition which unites MEPs across political divisions even though not all of them are Christian. Accordingly, not all MEPs consider the protection of freedom of religion and of the rights of religious and secular minorities to be an issue of religion, but rather as an issue of fundamental rights.

In parliamentary speeches, motions and questions, religion is most often referred to in Muslim contexts as most of the countries focused upon have Muslim majority populations, such as Pakistan, Iran, Iraq, Bahrain, Yemen and Kazakhstan, as well as Egypt, Syria and Turkey. However, German MEPs also often refer to freedom of religion and religious minorities in other countries, such as Tibet, Myanmar, Russia, Vietnam, North Korea and Belarus. ${ }^{8}$ A strong focus lies on the protection of Christian minorities, but minorities from other religions are also referred to, including Islam, Buddhism, Baha'i, Hinduism, Jehovah's Witnesses, Falun Dafa, Ahmadis, as well as, in some cases, the rights of converts and secular people. Jews are primarily referred to in EU internal affairs in activities against discrimination on grounds of religion, including most prominently Antisemitism and Islamophobia.

The concentration on the rights of religious minorities in the parliamentary activities of the German MEPs is one reason why religion is referred to in a primarily positive way. One major exception is Islam, on which negatively framed references outweigh positive ones (by all political groups). It is often placed in the context of intolerance and extremism, as well as violence and conflict. ${ }^{9}$ However, differences between political groups are important to mention here. When we calculate positively and negatively connoted references to Islam, we find that the German EPP and ALDE members are more critical towards Islam in their speeches, motions and questions than are the Greens and the Left; on Christianity, German EPP members are not critical at all.

Besides EU external affairs, German MEPs' views on policy sectors and thematic debates in which religion is most salient diverge. Fundamental rights are also perceived as important, including issues such as women's and reproductive rights, rights to life, and the rights of sexual minorities. A field particularly often stressed by German MEPs was bioethics, such as genetic engineering, stem cell research and pre-implantation genetic diagnosis. Further fields often mentioned in the interviews include development cooperation, enlargement, environmental protection, asylum and integration, social policy, culture and

8 We name here only countries that were referred to at least ten times. A complete list can be obtained from the authors.

9 Given the limited scope of this paper, we can focus here only on major trends and do not report about alternative views on issues reflected in our content analysis. 
education, global food protection, family policy. However, as our content analysis of parliamentary activities reveals, these are fields that German MEPs almost never frame in explicitly religious terms. Our interpretation therefore is that these policy fields are more implicitly affected by religious values (without explicit reference to them), as well as by interventions by religious interest groups, such as the churches, which, at least in Germany, are strongly involved in many of those debates.

A 'special case' in the debate about religion in EP politics is the accession of Turkey to the EU, which is not only about adding one more country to the EU but also about the identity and the borders of Europe (Minkenberg 2012, 150). 68\% of the German respondents think that religion is an important issue in the debate about Turkey's accession, but many of them perceive this impact only in a subtle way, for instance when opponents of Turkey's accession highlight cultural differences to obscure their reservations against Islam. The fact that the major German churches have been sceptical about Turkey's accession to the EU, primarily on grounds of non-respect for religious freedom and of cultural and value-based differences from the other EU members (Minkenberg 2012, 160-163), also suggests a more hidden religious factor in the EP, although religion is not explicitly referred to in debates. $32 \%$ think religion does not play a role at all.

Religion itself is not regarded by most of the surveyed German MEPs as an issue requiring a common approach by the EU. The case of a reference to the Christian heritage in the Treaty of Lisbon, by contrast, is clearly an issue that divides the included German MEPs into two groups: believers in the EPP and all others. That a reference to the Christian heritage or even God was not included in the Treaty, despite extensive mobilising by EPP members and religious organisations, suggests that there is no majority in the EP for overtly religious positions. $^{10}$

\section{Religious affiliation and religiosity: German MEPs and MBs in comparison}

One important question in the study of religion and political elites is whether political elites mirror religious trends within their societies (Oermann 2007: 151). Therefore, we shall now assess whether German politics at the European level is more or less secularised than at the national level, and whether parliamentarians represent the religious social structure of German

10 This assumption corresponds to the impression of some of the interviewed MEPs. Another anecdotal evidence from our interviews for this assumption is the failed attempt of an Italian MEP to establish an intergroup on Christian family values. 
society at large. To this end, we complemented our original data with a review of CVs on the personal websites of all German MEPs and an additional mini survey, asking the German MEPs only about their religious affiliation and personal faith, which eventually provided us with information on the religious affiliation of $54.5 \%$ of all German MEPs, and on subjective religiosity of $45.5 \%$.

According to our data, about $38.9 \%$ of German MEPs are Catholic and $38.9 \%$ Protestant, $1.9 \%$ are Muslim, and $20.4 \%$ are unaffiliated with any religion. Reflecting parity between the two major Christian faiths in Germany, Christian church members are significantly overrepresented in the EP compared with the $29.4 \%$ of each of the two major denominations in Germany. People of no confession are significantly underrepresented compared with their share of $32.5 \%$ in the German population (Table 1). However, as we stated earlier, we assume a bias towards church members and religious MEPs in our sample. But even if the numbers do not allow conclusive findings about the distribution of denominations among Germans in the EP, they do mirror some trends which we also find among members of the German Bundestag (MBs) (Table 4).

Table 4. Religious preferences of German MBs, 2010 (\%).

\begin{tabular}{|l|r|}
\hline Catholic & 30.5 \\
\hline Protestant & 28.5 \\
\hline Muslim & 0.5 \\
\hline No confession & 4.3 \\
\hline Atheist & 0.3 \\
\hline Not specified & 35.9 \\
\hline
\end{tabular}

Source: Amtliches Handbuch des deutschen Bundestages 2010.

Despite individual secularisation processes in German society, numbers of Christians in the German Bundestag have remained relatively stable (Oermann 2007). The overrepresentation might be caused by the fact that Christian church members in Germany are disproportionately often involved in civic and political engagement (Liedhegener 2011; Traunmüller 2009, Roßteutscher 2009). After reunification, Protestants were particularly overrepresented in the Bundestag as the Protestant Church was the largest church in the GDR and provided an important base for the opposition movement there. In many cases, political elites were recruited from this group, although their presence in politics has started to dwindle 
(Oermann 2007, 157-158). Recently the proportion of Protestants has dropped below the proportion of Catholics in the Bundestag (Figure 1). The majority of MBs do not specify their

Figure 1. Denominations in the German Bundestag, 1990-2010 (\%).

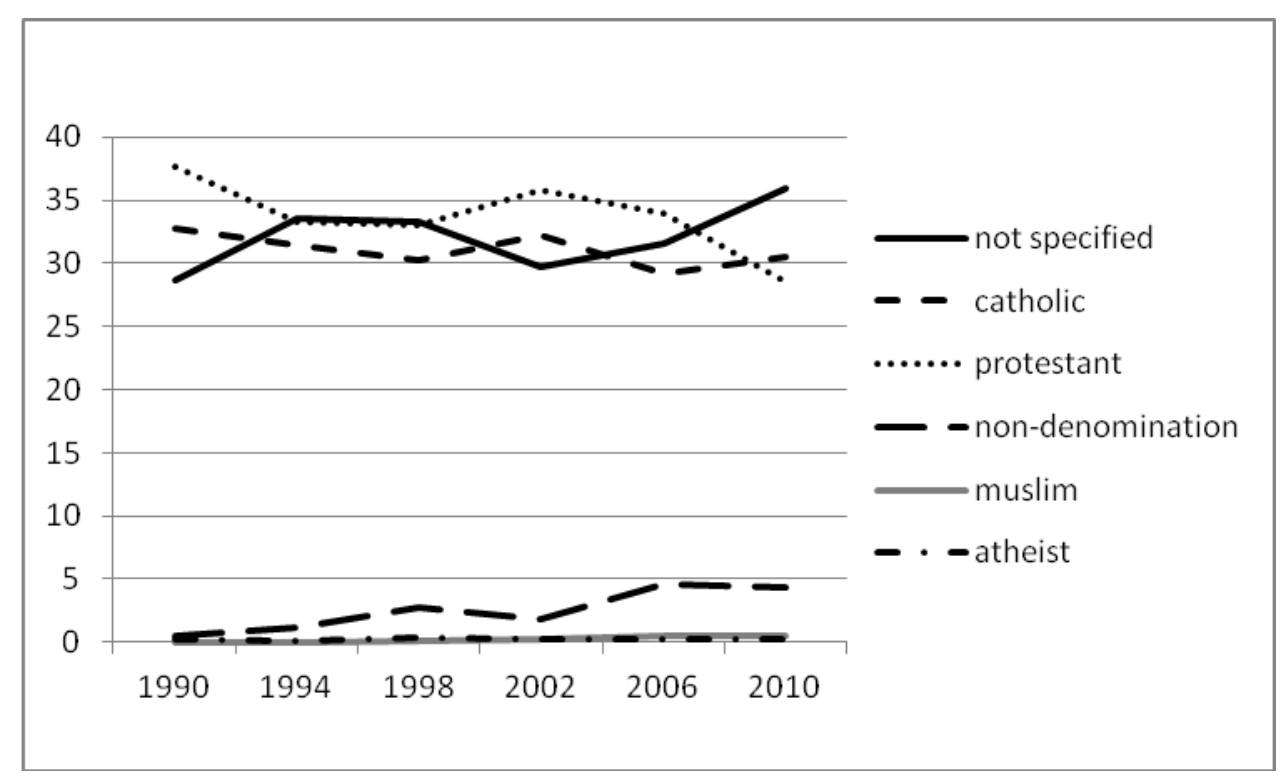

Source: Amtliches Handbuch des deutschen Bundestags 2010.

religion (Figure 1). We cannot say whether they have just not given any details or whether religion plays no role in their lives. This group of MBs has been increasing over the last 20 years (Figure 2), suggesting a trend towards the privatization of religion. Catholics, in the German Bundestag, as well as in our sample of the EP, are primarily represented in the CDU/CSU (and the EPP), whereas Protestants are more evenly distributed amongst all parties. The members of the CDU/CSU in the Bundestag seem also to be more religious, as about $6 \%$ do not specify their religious preferences, whereas in the other parties the figure considerable higher. Most of the MBs without religious preferences can be found, as expected, in the Left and the Green parties (Figure 2).

Figure 2. Religious preferences in the German Bundestag by party, 1990-2010 (\%). 


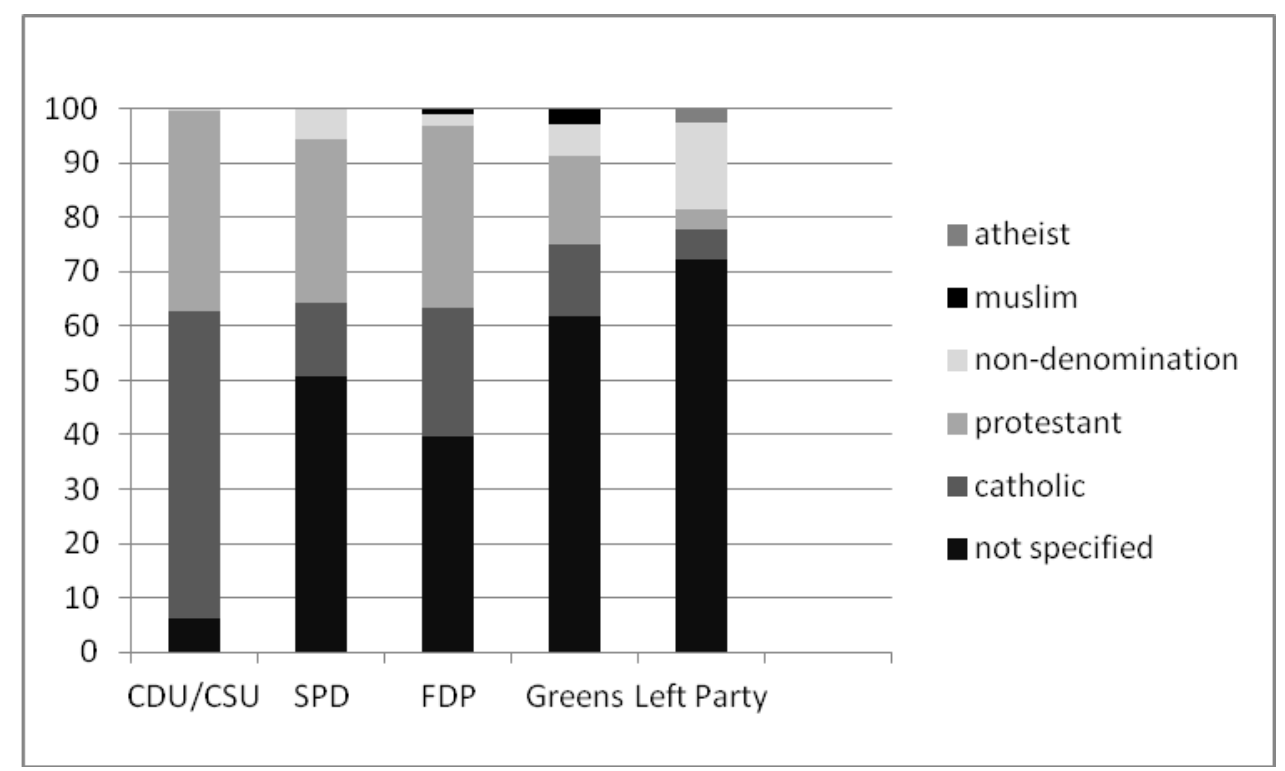

Source: Amtliches Handbuch des deutschen Bundestages 2010.

A similar distribution can be found among the German MEPs in the EP. All included MEPs from the EPP (as well as ALDE) also define themselves as religious (with two exceptions who did not want to provide information on this question). The majority of them attend church more than once a year. Other groups, such as the S\&D, the Greens and the Left, are more mixed with respect to the presence of both religious and non-religious MEPs. Although the total numbers included in the survey are small, they do suggest that the EPP among German MEPs is the most religious group, and the S\&D and the Left are the least religious: the five convinced atheists from our (extended) sample (11.1\%) are members of these two groups.

$66.7 \%$ of German MEPs who responded to our surveys define themselves as religious. In the German Bundestag, about $60 \%$ of the MBs do so (Amtliches Handbuch des deutschen Bundestages 2010). Both numbers correspond relatively well with the number of believers in German society, where about two thirds believe in a God (Pickel 2013, 83). As in society at large, the proportion of believers in the German Bundestag has decreased: from about $70 \%$ in 1990 to 60\% in 2010 (Amtliches Handbuch des deutschen Bundestages 2010).

Our data thus suggest relatively similar patterns of religious affiliation and religiosity in the EP and the German Bundestag. This to some degree also represents societal trends in Germany. However, German political elites appear to be more Christian and religious than the German average population.

If we compare the presence of religion in terms of religious interest-groups and arguments, though, the Bundestag seems to be more religious than the EP. According to 
Mariano Barbato, the German Bundestag is a 'post-secular location' which admits religious communities and respects religious argumentation (Barbato forthcoming 2014). The specific arrangement is contested, but there is not a strict separation of religious discourse from the presence of a secular institution. However, explicit references to religion are not integrated into the day-to-day work of the Bundestag but confined to particular debates. If these debates relate to questions of conscience, parliamentary groups lift party discipline and allow the MBs to vote freely. In such debates, for example on pre-implantation diagnostics, MBs also exchange explicitly religious arguments and argue about different images of God and religious beliefs (Barbato forthcoming). Other issues on which party discipline have been lifted include topics such as the living will, late-term abortions, genetic engineering, the foreign assignment of German armed forces and the fight against terrorism.

Many MBs, furthermore, traditionally maintain close contacts with the German Bishops' Conference and the EKD. Each parliamentary group has its own representative for churches and religious communities; they are often also members of prominent religious institutions such as the Synode der Evangelischen Kirche Deutschland and the Zentralkomitee der deutschen Katholiken (Deutscher Bundestag 2012).

These considerations correspond well with the views of many of the consulted German MEPs: $60 \%$ of them think that the place of religion in the EP and in European politics differs from the position in Germany. Most think that religion is less salient in European than in German politics. One piece of evidence, often referred to in the interviews, is the fact that the German Bundestag offers many more structures for religious contemplation, spiritual exchange and religious networking than the EP. There exists a (multi-religious) prayer room within the Bundestag, in which religious communities organise religious services; there is a weekly 'prayer breakfast' in parliamentary premises near the building of the Bundestag; and the cross-party group 'Christians in Parliament' is regularly represented at the Kirchentag with its own stand (Deutscher Bundestag 2012). MEPs, by contrast, have to organise regular religious services and 'prayer breakfasts' outside the EP.

German MEPs, regardless of whether religious or not, explain the lesser presence of religious and ethical themes, debates and voices in the EP by the larger religious and cultural diversity in the EP and a considerable participation of states with strict separation between church and state, making religion too conflictual an issue to integrate in the day-to-day work of the EP. The MEPs noticing a stronger role of religion in the EP than in Germany ascribe this to European struggles to find a common identity and more explicit expressions of religious beliefs by MEPs from other countries, particularly from the south of Europe. 


\section{Conclusions}

As demonstrated in the previous sections of this article, the influence of the German model of publicly dealing with religion is, to a certain extent, mirrored in the perceptions, attitudes and activities of German MEPs. The churches are largely recognised as important mediators of social interests. Religion is affirmatively referred to in speeches, motions and questions, primarily as a matter of human rights of religious minorities, facilitating a relative consensus across believers and nonbelievers as well as different denominations, because all MEPs, irrespective of individual religiosity or religious affiliation, can agree on this fundamental European value. The explicit referencing of religion, due to its focus on Christian minorities in Muslim countries outside the EU, as well as negative connotations of Islam, however, also contribute to symbolically drawing boundaries between a Christian or secular Europe and Islam as an 'external other'.

The EP certainly is less 'post-secular' than the German Bundestag. Explicitly religious arguments and issues are largely absent from the EP. Due to the EP's great diversity, religion appears to be too conflictual an issue to be brought up explicitly and frequently. Leaving religion as a subject and explicit pattern of argumentation out of the EP is the smallest common denominator allowing efficient day-to-day work. However, as our article has demonstrated this does not necessarily mean that the level of religiosity in the EP is particularly low, that religious values do not affect individual decisions, and that religious interest groups are not received well. Hence religion does affect the workings of the EP but still in a more subtle way. The question of whether and how this might be changing and with what consequences will have to be answered by future research.

\section{Notes on Contributors}

Anne Jenichen holds a doctoral degree in Political Science from the University of Bremen. As a senior researcher and lecturer, she is based at the Jean Monnet Centre for European Studies at the University of Bremen. Her research interests include issues of European integration, European foreign policy, the impact of international institutions, multi-level governance, religion and politics, gender and politics, and post-war reconstruction. She is author of the book "Politische Innovation in internationalisierten Nachkriegskontexten - Bosnische Frauenrechtspolitik in vergleichender Perspektive“ [Policy Innovation in internationalized 
post-war contexts - Bosnian women's rights policy in comparative perspective] (Wiesbaden: Springer VS, 2012) and co-editor of a special issue on "The Unhappy Marriage of Religion and Politics: problems and pitfalls for gender equality" (with Shahra Razavi, Third World Quarterly, 31:6/2010).

Henrike Müller is senior researcher at the Department of Political Science at the University of Bremen. She holds a PhD in Social Science. Her research interests are European Integration Theory, Gender Studies, European Migration Policy, Religion and Politics. At present she works on the research project "What direction for Europe? Elections to the European Parliament 2014: new issues and strategies?"

\section{References}

Amtliches Handbuch des deutschen Bundestages 2010 [Official Handbook of the German Bundestag], hrsg. vom Deutschen Bundestag, Rheinbreitbach: Neue Darmstädter Verlagsanstalt.

Barbato, Mariano (forthcoming 2014), "Postsäkulares Parlament: Der Deutsche Bundestag als postsäkularer Ort" [Postsecular Parliament: The German Bundestag as postsecular location]. In Religionspolitik in der Bundesrepublik Deutschland [Religious Politics in the Federal Republic of Germany], edited by G. Pickel, and A. Liedhegener. Wiesbaden: Springer VS.

Bösch, F. 2013. "Christlich-Demokratische Union Deutschlands (CDU)" [ChristianDemocratic Union Germany]. In Handbuch der deutschen Parteien [Handbook of German Parties], edited by F. Decker, and V. Neu, 203-218. Wiesbaden: Springer Fachmedien.

Cavuldak, A. 2013. "Die Legitimität der hinkenden Trennung von Staat und Kirche in der Bundesrepublik Deutschland" [The Legitimacy of the Limping Separation of State and Church in the Federal Republic of Germany]. In Religion und Politik im vereinigten Deutschland: was bleibt von der Rückkehr des Religiösen? [Religion and Politics in united Germany: What's left of the Return of the Religious?], edited by G. Pickel, and O. Hidalgo, 307-335. Wiesbaden: VS Verlag für Sozialwissenschaften. 
Davie, G. 2012. "A European Perspective on Religion and Welfare: Contrasts and Commonalities." Social Policy and Society 11 (4): 589-599.

de Nève, D. 2013. "Islamophobie in Deutschland und Europa" [Islamophobia in Germany and Europe]. In Religion und Politik im vereinigten Deutschland: Was bleibt von der Rückkehr des Religiösen? [Religion and Politics in united Germany: What's left of the Return of the Religious?], edited by G. Pickel, and O. Hidalgo, 195-220. Wiesbaden: VS Verlag für Sozialwissenschaften.

Deutscher Bundestag (2012), Die Abgeordneten und ihr Glaube [The Representatives and their Faith], download: https://www.btg-bestellservice.de/pdf/20057000.pdf (last access: 21 March 2014).

Elff, M., and S. Rossteutscher. 2011. "Stability or Decline? Class, Religion and the Vote in Germany." German Politics 20 (1): 107-127.

Gerngroß, M. 2010. "(K)eine Bindung auf ewig: die CSU und die Kirchen" [No Tie in Perpetuity: the CSU and the Churches]. In Die CSU: Strukturwandel, Modernisierung und Herausforderungen einer Volkspartei [The CSU: Structural change, Modernisation and Challenges of a Catch-All Party], edited by G. Hopp, M. Sebaldt and B. Zeitler 7798. Wiesbaden: VS Verlag für Sozialwissenschaften.

Göçmen, İ. 2013. "The Role of Faith-Based Organizations in Social Welfare Systems: A Comparison of France, Germany, Sweden, and the United Kingdom." Nonprofit and Voluntary Sector Quarterly, Apr. 3. doi: 10.1177/0899764013482046.

Götze, C., Y. Jaeckel, and G. Pickel. 2013. "Religiöse Pluralisierung als Konfliktfaktor? Wirkungen religiösen Sozialkapitals auf die Integrationsbereitschaft in Deutschland" [Religious Pluralisation as Factor of Conflict? Effects of Religious Social Capital on the Willingness to Integrate in Germany]. In Religion und Politik im vereinigten Deutschland: Was bleibt von der Rückkehr des Religiösen? [Religion and Politics in united Germany: What's left of the Return of the Religious?], edited by G. Pickel, and O. Hidalgo, 271-304. Wiesbaden: VS Verlag für Sozialwissenschaften.

Hering, R. 2011. "SPD und Kirchen in Deutschland" [The SPD and the Churches in Germany], Neue Gesellschaft: Frankfurter Hefte 4: 43-46.

Liedhegener, A. 2011. “'Linkage' im Wandel: Parteien, Religion und Zivilgesellschaft in der Bundesrepublik Deutschland" [Changing Linkage: Parties, Religion and Civil Society in the Federal Republic of Germany]. In Religion zwischen Zivilgesellschaft und 
politischem System: Befunde - Positionen - Perspektiven [Religion between Civil

Society and Political System: Findings - Positions - Perspectives], edited by A.

Liedhegener, and I.-J. Werkner, 232-256. Wiesbaden: VS Verlag für

Sozialwissenschaften.

Liedhegener, A. 2012. "'Da capo' im Wahlkampf 2009? Die Unionsparteien und die Debatte um das 'C'" [Da capo in the Electoral Campaign of 2009? The Christian Democratic Parties and the Debate about the C]. In Sphärendynamik II: Religion in postsäkularen Gesellschaften [Sphere Dynamics II: Religion in Postsecular Societies], edited by G. Pfleiderer, and A. Heit, 241-258. Baden-Baden: Nomos.

Manow, P., and K. van Kersbergen. 2009. "Religion and the Western Welfare State: The Theoretical Context." In Religion, Class Coalitions, and Welfare States, edited by K. van Keersbergen and P. Manow, 1-38. Cambridge: Cambridge University Press.

Minkenberg, M. 2009. "Religion and Euroscepticism: Cleavages, Religious Parties and Churches in EU Member States." West European Politics 43 (6): 1190-1211.

Minkenberg, M. 2012. "Christian Identity? European Churches and the Issue of Turkey's EU Membership." Comparative European Politics 10 (2): 149-179.

Minkenberg, M. 2013. "Religion und Politik in Europa: alte Fragen und neue Herausforderungen" [Religion and Politics in Europe: Old Questions and new Challenges]. In Europa-Studien: eine Einführung [European Studies: An Introduction], edited by T. Beichelt, C. Bozena, G. C. Rowe, and H.-J. Wagner, 53-71. 2nd ed. Wiesbaden: VS Verlag für Sozialwissenschaften.

Oermann, N. O. 2007. "The Importance of Religious Affiliation among Political Elites: A comparison of Germany and the United States." In Religion and Politics in the United States and Germany, edited by D. Pruin, R. Schieder, and J. Zachhuber, 149-173. Münster: LIT.

Pappi, F. U., and J. Brandenburg. 2010. "Sozialstrukturelle Interessenlagen und Parteipräferenz in Deutschland: Stabilität und Wandel seit 1980" [Sociostructural Ranges of Interests and Party Preferences in Germany: Stability and Change since 1980]. Kölner Zeitschrift für Soziologie und Sozialpsychologie 62 (3): 459-483.

Pappi, F. U., and S. Shikano. 2002. "Die politisierte Sozialstruktur als mittelfristig stabile Basis einer deutschen Normalwahl" [The politicised Social Structure as stabile Basis 
of a German Normal Election]. In: Kölner Zeitschrift für Soziologie und Sozialpsychologie, 54:3, 444-475.

Pickel, G. 2013. "Die Situation der Religion in Deutschland: Rückkehr des Religiösen oder voranschreitende Säkularisierung?" [The Situation of Religion in Germany: Return of the Religious or progressing Secularization?]. In Religion und Politik im vereinigten Deutschland: was bleibt von der Rückkehr des Religiösen? [Religion and Politics in united Germany: What's left of the Return of the Religious?], edited by G. Pickel, and O. Hidalgo, 65-101. Wiesbaden: VS Verlag für Sozialwissenschaften.

Roßteutscher, S. 2009. Religion, Zivilgesellschaft, Demokratie: eine international vergleichende Studie zur Natur religiöser Märkte und der demokratischen Rolle religiöser Zivilgesellschaften [Religion, Civil Society, Democracy: A Comparative International Study of the Nature of Religious Markets and the Democratic Role of Religious Civil Societies]. Baden-Baden: Nomos.

Sebaldt, M., and A. Straßner. 2004. Verbände in der Bundesrepublik Deutschland: Eine Einführung [Associations in the Federal Republic of Germany]. Wiesbaden: VS Verlag für Sozialwissenschaften.

Spielhaus, R. 2013. "Vom Migranten zum Muslim und wieder zurück: Die Vermengung von Integrations- und Islamthemen in Medien, Politik und Forschung" [From Migrant to Muslim and back again: Mixing Issues of Integration and Islam in the Media, in Politics and Research]. In Islam und die deutsche Gesellschaft [Islam and German Society], edited by D.Halm, and H. Meyer, 169-194. Wiesbaden: VS Verlag für Sozialwissenschaften.

Tezcan, L. 2011. "Repräsentationsprobleme und Loyalitätskonflikte bei der Deutschen Islam Konferenz" [Problems of Representation and Conflicts of Loyality at the German Islam Conference]. In Politik und Islam [Politics and Islam], edited by H. Meyer and K. Schubert, 113-132. Wiesbaden: VS Verlag für Sozialwissenschaften.

Thériault, B. 2004. "Conservative Revolutionaries": Protestant and Catholic Churches in Germany After Radical Political Change in the 1990s. New York/Oxford: Berghahn Books.

Traunmüller, R. 2009. "Religion und Sozialintegration: Eine empirische Analyse der religiösen Grundlagen sozialen Kapitals" [Religion and Social Integration: An 
Empirical Analysis of the Religious Foundations of Social Capital]. In: Berliner Journal für Soziologie 19 (3): 435-468.

Willems, U. 2007. "Kirchen" [Churches]. In Interessenverbände in Deutschland [Interest Groups in Germany], edited by T. von Winter, and U. Willems, 316-340. Wiesbaden: VS Verlag für Sozialwissenschaften.

Wohlrab-Sahr, M. 2003. "Politik und Religion: 'diskretes' Kulturchristentum als Fluchtpunkt europäischer Gegenbewegungen gegen einen 'ostentativen' Islam" [Politics and Religion: Discreet Christian Culture as Focus of European Counter-Movements against an ostentatious Islam]. In Der Begriff des Politischen [The Notion of Politics], edited by A. Nassehi, and M. Schroer, 357-381. Baden-Baden: Nomos. 